\title{
OELS DERIVATION IN POLAND AND IN THE FORMER EASTERN BLOC WITH REFERENCE TO APPROACHES AND PRACTICES APPLIED IN THE EU
}

\author{
USTALANIE DOPUSZCZALNYCH POZIOMÓW NARAŻENIA ZAWODOWEGO \\ W POLSCE I PAŃSTWACH DAWNEGO BLOKU WSCHODNIEGO W ŚWIETLE PODEJŚCIA I ROZWIAZZAŃ UE
}

Nofer Institute of Occupational Medicine / Instytut Medycyny Pracy im. prof. J. Nofera, Łódź, Poland

Department of Chemical Safety / Zakład Bezpieczeństwa Chemicznego

\begin{abstract}
Based on the literature, current legislation and the European Union (EU) directives, the rules to protect the health of workers in Poland and the countries of the former Eastern Bloc were analyzed. Since 2002, the activities in the field of hygiene standards in the countries of the former Eastern Bloc have been correlated with the EU policy. The functioning of the system of maximum admissible concentrations (MAC) having been implemented in Poland for many years before the accession to the EU, has provided for a relatively quick adjustment of Polish regulations on chemicals to the relevant European law. The Polish list includes 543 substances. In the former Eastern Bloc countries, intensification of work after joining the EU has caused the lists in those countries to contain from 285 substances in Slovakia to 780 in Lithuania. Currently, all substances included in the EU lists (up to and including the 3rd list of occupational exposure limit values of the Directive 2009/161/EC) have been governed by the Polish, Lithuanian, Czech, Latvian and Hungarian law. In Estonia and Slovakia the provisions of the Directive 2006/15/EC establishing the second list of occupational exposure limits have been implemented. Individual national lists contain much more chemicals than the EU list containing currently 122 substances. The legislative process in the EU is slow, and that is why the national law is important and necessary due to the local needs in selected areas. It is necessary to correlate the activities in the field of determining regional occupational exposure limit (OEL) values in the countries of the Eastern Bloc and the EU. Med Pr 2015;66(3):383-392
\end{abstract}

Key words: Poland, UE, Eastern Europe, occupational exposure, MAC-TWA, MAC-STEL

\section{STRESZCZENIE}

W oparciu o dane literaturowe, aktualne akty prawne i dyrektywy Unii Europejskiej (UE) przedstawiono zasady ochrony zdrowia pracowników w Polsce i państwach dawnego bloku wschodniego. Od 2002 r. zadania w obszarze normatywów higienicznych w tych państwach są skorelowane z polityką UE. Funkcjonowanie w Polsce systemu ustalania wartości najwyższych dopuszczalnych stężeń (NDS) przez wiele lat przed wejściem do UE pozwoliło szybko dostosować polskie przepisy dotyczące chemikaliów do prawa europejskiego. Obecnie w polskim wykazie dopuszczalnych poziomów narażenia zawodowego znajdują się 543 substancje. W państwach byłego bloku wschodniego zintensyfikowanie prac nad ustaleniem tych poziomów po wejściu do UE spowodowało, że w wykazach tych państw znajduje się od 285 substancji (na Słowacji) do 780 (na Litwie). Obecnie wszystkie substancje w wykazach dopuszczalnych poziomów narażenia zawodowego w UE (do trzeciego wykazu wartości narażenia zawodowego opublikowanego w dyrektywie 2009161/EC włącznie) zostały wprowadzone do prawa polskiego, litewskiego, czeskiego, łotewskiego i węgierskiego. W innych państwach bloku wschodniego - Estonii i Słowacji - wdrożono przepisy dyrektywy 2006/15/WE ustanawiającej drugi wykaz wartości narażenia zawodowego w UE. Indywidualne wykazy krajowe zawierają znacznie więcej substancji niż wykaz UE (w którym są obecnie 122 substancje). Proces legislacyjny w UE jest powolny, dlatego wartości krajowe są ważne i potrzebne ze względu na lokalne potrzeby w wybranych dziedzinach i konieczność samodzielnych rozwiązań problemów. Niezbędne jest skorelowanie działań w zakresie ustalania regionalnych wartości dopuszczalnego narażenia zawodowego (occupational exposure limit - OEL) w krajach dawnego bloku wschodniego i w UE oraz wymiana informacji wynikających z przetworzenia olbrzymiej ilości danych literaturowych. Med. Pr. 2015;66(3):383-392

Słowa kluczowe: Polska, UE, Europa Wschodnia, narażenie zawodowe, NDS, NDSCh

Corresponding author / Autorka do korespondencji: Renata Soćko, Nofer Institute of Occupational Medicine, Department of Chemical Safety, św. Teresy 8, 91-348, Łódź, Poland, e-mail: socko@imp.lodz.pl Received: October 23, 2014, accepted: December 22, 2014

Funding / Finansowanie: the publication is based on the results of Phase III of the National Programme "Safety and working conditions improvement," funded in the years 2014-2016 in the area of tasks related to services for the State by the Ministry of Labour and Social Policy. The programme coordinator: Central Institute for Labour Protection - National Research Institute. 


\section{INTRODUCTION}

Principles of health care for workers in Poland and the countries of the former Eastern Bloc had been governed for many years prior to their accessing the European Union (EU). The first attempt in that respect was to set the "safe" concentrations for 6 chemicals in the former Union of Soviet Socialist Republics (USSR) in 1920, while 1933 saw the publication of the first list of "safe levels" for 14 substances.

In Poland, the history of hygiene standards for harmful agents in the working environment is almost 60 years old. The 1st list of hygiene standards was released in 1956, and it included the substances found in the Soviet list [1]. Those initial standards did not refer to the weighted average values, but to the single exposure and the momentary exposure to a value above the admissible limit, which was regarded as a violation of sanitary regulations.

In 1959, during the 1st international symposium of the International Union of Pure and Applied Chemistry (IUPAC) in Prague, the participants coined the definition of the maximum admissible concentration: "The average concentration of substances in the air that does not cause symptoms of disease or physical impairment - detectable by the most sensitive tests - in any of the exposed workers, with the exception of sensitive individuals, during their normal work."

In 1959, the Polish list of sanitary standards contained the values for 127 substances. In Hungary, the first list was published in 1954 and included standards for 64 chemicals. In 1950-1960 the limits were adopted not only from the Soviet list, but also from the list of the American Conference of Governmental American Industrial Hygienists (ACGIH), published in 1947. The association of the countries of the European Economic Community in 1991 issued a directive on the protection of workers, that included a recommended list of $27 \mathrm{sub}$ stances with limit values, for which the scientific basis for setting the standards had been developed [1].

On 1 May, 2004, pursuant to the Treaty of Accession, Poland, Estonia, Lithuania, Latvia, Slovakia, Hungary and the Czech Republic joined the EU, but the process of their integration had begun much earlier, at the moment of submission of applications for the EU membership. Those countries were preparing for many years to integrate into the $\mathrm{EU}$ in the field of hygiene standards for working environment. Currently, the principle of the protection of the health of workers in these countries is governed by the law. Although the systems of setting the hygiene standards in Poland and the Eastern Bloc vary, the main objective of all countries is to ensure safe and healthy working conditions for the workers. This obligation rests with the employer and includes a wide set of standards and rules, the enforcement of which is intended to prevent accidents at work and to ensure that jobs are performed in a way that minimizes the impact on health of the adverse agents prevailing in the working environment. The employer is obliged, inter alia, to determine whether a chemical agent that is a likely source of health hazard is found in the working environment, and also assess and document the risk to human health attributable to that agent.

Determinations of workplace concentrations of chemical agents referred to the adopted exposure limits are usually used for the evaluation of occupational exposure to chemical agents and the associated risks. The values of maximum admissible concentrations (MAC) thus serve as a criterion for the assessment of occupational exposure and the associated risks. The definition of the maximum admissible concentration - the timeweighted average (MAC-TWA) of a chemical in the air of the working environment (the concentration that, affecting an employee $8 \mathrm{~h} /$ day and $40 \mathrm{~h} /$ week for his/her whole work-life span, does not cause adverse changes in his/her health condition nor results in disease or ill-health) is the same in the countries of the Eastern Bloc and Poland.

Some of these countries define the maximum admissible concentration differently - short-term exposure limit (MAC-STEL). In Poland, the MAC-STEL is defined as the average concentration that does not cause adverse changes in the health of the worker if it persists in the working environment no longer than $15 \mathrm{~min}$ and occurs maximum twice during 1 work shift at time interval not shorter than $1 \mathrm{~h}$. In Slovakia and Lithuania, the value of the short-term exposure limit (named: NPEL kratkodobý and TPRD - trumpalaikio poveikio ribinis dydis, respectively) is defined as the concentration that is not to be exceeded, is not allowed to last longer than $15 \mathrm{~min}$ and occur more than 4 times during 1 work shift. In Estonia, the MAC-STEL value (named: lühiajalise kokkupuute piirnorm või piirnormi lagi), and in Latvia (named: AER islaicīgi, peak concentration) is also measured during the 15 min exposure, but without specifying how many times during the shift. In Latvia, it has been also decided that exposure to a fibrogenic substances is not allowed to exceed $30 \mathrm{~min}$. In turn, in the Czech Republic, the MAC-STEL (na-med: NPK$\mathrm{P}$ - nejvyšší přípustné koncentrace) is the maximum 
admissible concentration recorded at any time during one 8 -h shift, which should not be exceeded. In Hungary, the instantaneous value of the normative (named: CK-érték) is 1-8 times the value of the timeweighted average (MAC-TWA), depending on the toxic potential of the chemical. It should not be exceeded, should not last longer than $15 \mathrm{~min}$, and should not occur more than 4 times during 1 work shift [2-8].

\section{MATERIAL AND METHODS}

Literature review was based on the scientific publications, current legislation and EU directives, and the rules to protect the health of workers in Poland and the countries of the former Eastern Bloc were analyzed.

\section{RESULTS}

We present a system for setting occupational exposure limits in Poland and in the countries of the former Eastern Bloc with reference to approaches and practices applied in the European Union.

\section{The system of setting OEL in Poland}

In Poland, the principles of protection of the health of workers are governed by the Labour Code [9]. The system of setting hygienic standards was launched in 1983 by the Minister of Labour, Wages and Social Affairs and the Minister of Health and Social Welfare who, by the Ordinance No. 33 of 27 June 1983, appointed the Interdepartmental Commission for Maximum Admissible Concentrations and Intensities for Agents Harmful to Health in the Working Environment. In 1996, the Prime Minister appointed the members of the Interdepartmental Commission [10]. This Commission makes decisions regarding the legislative process in the area of standardization of admissible concentrations of chemical substances in the working environment. The Commission is composed of employees of the Ministries of Health and Labour, as well as of the representatives of industry and academic institutions.

The Commission established the Group of Experts for Chemical Agents (GECA), whose tasks involved studies on limits of occupational exposure to chemicals and dusts and which, by 2013, developed and verified 590 monographs containing detailed information on occupational exposures, physical, chemical and toxicological characteristics in animals and humans. Those monographs are published in Polish in the Interdepartmental Commission's quarterly magazine, Principles and Methods for Assessment of Working Environment, and contain abstracts in the English language, which facilitate wide access to these publications in the European forum.

In 2004, at the time of signing of the Treaty, it was necessary to prepare 76 monographs in order to extend the list of Polish MAC values to the scope applicable in the EU. At that time, the MAC list included 441 chemicals and 19 dusts. The current list of MAC values specified in the Regulation of the Minister of Labour and Social Policy of 2014 contains 524 chemicals and 19 dusts [2].

\section{Overview of approaches and practices for setting the levels of occupational exposure in the former Eastern Bloc and the European Union Former Eastern Bloc}

The most numerous list of occupational exposure limits has been prepared in the Republic of Lithuania, where the principles of worker health care are included in the Labour Code, which takes into account the experience of the countries of Central and East Europe that have already reformed their labour law (Hungary, Czech Republic, Poland), and which have also adapted a number of provisions of the Directives of the European Union.

The Lithuanian regulations comply with basic EU rules and with the regulations of the International Labour Organization and the European Social Charter (as subsequently amended). Compliance with regulations on worker safety and health is controlled by the National Labour Inspectorate. The activities, rights and responsibilities of the National Labour Inspectorate are specified in the Law on National Labour Inspectorate. In order to reconcile the interests of the state, employers and employees in the area of health and safety at work, the Commission for Occupational Safety and Health of the Republic of Lithuania has been established - in accordance with the principle of tripartite cooperation between social partners. Workplace exposure limits can be found on the webpage of the Lithuanian Parliament [4]. The Lithuanian list contains 780 dangerous substances for which time-weighted average values (dinaminis svertinis vidurkis - DSV) have been set. This act implements the provisions of the Directive 2009/161/EC establishing a third list of indicative occupational exposure limit values [11].

In Estonia, the hygiene standards are drafted and approved by the Ministry of Social Affairs. Their values are based on the current list of maximum admissible concentrations valid in the European Union and Sweden. The Estonian list is being continuously updated, 
according to the changes made in the legislation of those countries. The participants of the process of setting the admissible concentrations include also health and safety inspectors, representatives of the chemical industry and representatives of other sectors. The Estonian list contains at present 555 dangerous substances, for which the MAC values have been set [5]. This Act implements the provisions of the Directive 2006/15/EC establishing a second list of indicative occupational exposure limit values [12].

Similarly, in the Czech Republic, occupational exposure limit (OEL) values for substances in the working environment are modified in accordance with the EU directives on dangerous chemicals. The values of admissible workplace concentrations set in the Czech Republic are binding. This is guaranteed by the Ministry of Health of the Czech Republic and the National Institutes of Health. The control is exercised by the Ministry of Health of the Czech Republic through the Division of the Head Health Officer and regional public health authorities. Besides, in different regions, separate OEL values may be set by local boards. These values must be recommended by the National Institute of Public Health. The list of 338 dangerous substances, for which the hygiene standards have been set in the Czech Republic is implemented by the provisions of the 2009 Directive [11] establishing a third list of indicative occupational exposure limit values [7].

In the territory of the Slovak Republic, the Ministry of Health of the Slovak Republic is the governmental body controlling the regulations on the OEL. A working group consisting of public and occupational health professionals established within the Ministry of Health is responsible for the preparation of the proposals for the standards, based on the occupational exposure limit values specified in the EU directives. The working group prepares a list of occupational exposure limit values for chemical substances, carcinogens and mutagens. Revisions of the hygiene standards are based on published scientific data, standards and values valid in the EU, Germany, Great Britain and Sweden. Occupational exposure limit values in Slovakia are binding values.

Additional legally binding values include 41 Biological Exposure Index (BEI) values, which are indicative values, except for the BEI for lead in blood, which is the binding value. Compliance with the standards in force is controlled by the Ministry of Health departments accountable for regional public health (a network of 36 institutions and the national public health authority) in association with the National Labour Inspectorate.
The Slovak list implementing the provisions of the 2006 Directive establishing a second list of indicative occupational exposure limit values [12] contains 285 dangerous substances, for which the NPEL (OEL) values have been set [3].

In Latvia, the basis for determining the values of the maximum concentrations of substances in the working environment is the Labour Protection Law and the "Requirements for the protection of labour in contact with chemicals in the workplace" issued by the Council of Ministers [6]. Occupational exposure limit values are set by the Latvian Standard Technical Committee on Occupational Environment in Latvia. The Committee members include experts of the Institute of Occupational Health and Environmental Protection, Public Health Agency, the Minister of Environmental Protection and Regional Development, the National Labour Inspectorate, and also representatives of trade unions and the Employers' Confederation of Latvia [6]. The Committee has surveyed the Directives 91/322/EEC, 96/94/EC, reports of the World Health Organization (WHO) and of the International Labour Organization (ILO), re-commending OEL values for dangerous substances in the working environment and the national standards of the Russian Federation (GOST - Gosudarstvennyi Standard, Russian Standard). Exposure limit values are determined as a result of the discussion among all members of the social group: industry experts, representatives of employers and employees.

Occupational exposure limit values are set at the level specified in the EU directive, or at a lower level than in the EU. In Latvia, 2 lists specifying the chemicals with OEL values are valid in parallel; the one contains the OEL values determined based on the EU directive and the second list specifies the OEL values determined using other sources, such as Russian Standard (GOST).

The Latvian list implementing the provisions of the 2009 Directive establishing a third list of indicative occupational exposure limit values [11] specifies 651 dangerous substances [6]. In the Latvian list, the chemical substances are identified by the Chemical Abstracts Service (CAS) number, or occasionally the European Inventory of Existing Commercial chemical Substances (EINECS) numbers; structural or chemical formulas are also included, which greatly facilitate the search in the list, because the relevant information is not always accessible on the websites in English.

Until 1978, Hungary used predominantly OEL values of the former Soviet Union. After 1978, those values were consecutively being changed to the values 
based on the Hungarian occupational health and work hygiene research and the results obtained from toxicological studies, taking into account annual reports of health authorities and the opinions of researchers of the National Institute of Occupational Health, and based on the analysis of the worldwide literature on research of chemicals. Some OEL values were adopted from other countries, other values have been replaced or changed, and still others have been determined from the results of experiments on animals (toluene, xylene isomers, ethylbenzene) $[13,14]$. The Hungarian list implementing the provisions of the 2009 Directive establishing a third list of indicative occupational exposure limit values [11] contains 339 dangerous chemicals [8]. The Chemical Abstracts Service numbers are used to identify the chemicals in the lists of hygiene standards, thus making it easier to search the list, because the latter is not always accessible on the website in English.

\section{The European Union}

In Europe, since 1995, work on setting the Indicative Occupational Exposure Limit Values (IOELV) for chemicals in the occupational environment has been continued by the Scientific Committee for Occupational Exposure Limits to Chemical Agents, the SCOEL, which has been formally established by the decision of the European Commission, to perform the scientific assessment of the risks associated with the chemical agents found in the working environment. Occupational exposure limit is the "maximum admissible concentration of a chemical agent in the air in the breathing zone, defined as the weighted average referred to a given exposure time." In practice, the reference period is the duration of a work shift, $8 \mathrm{~h}$ (OEL-TWA - time weighted average). For some substances, the OEL-STEL (short time exposure limits) are set, for which the reference period is $15 \mathrm{~min}$. The EU has introduced 2 types of admissible limits:

1. Binding occupational exposure limit values (OEL-BOELV) - determined from health criteria, risk assessment and socio-economic factors.

2. Indicative occupational exposure limit values (IOELV) - based solely on health criteria.

For any chemical agent, for which an indicative occupational exposure limit value has been set at the Community level, the Member States are obliged to set a national occupational exposure limit value, taking into account the Community limit value. The Member States may, however, determine the nature of the admissible value in accordance with national legislation and practice, i.e., the set value may be higher or lower. In contrast to the IOELV that are implemented into EU law by the Council Directive, the BOELV are introduced by the decision of the Commission and the European Parliament.

For chemicals with set BOELV values, these values must be included in the national legislation as minimum requirements, i.e., Member States are required to set limit values that do not exceed the binding value. The European Union Directives 98/24/EC, 91/322/ EEC, 2000/39/EC, 2006/15/EC and 2009/161/EC contain lists of the IOELV values for 122 chemicals $[11,12,15-17]$. Currently, in the EU, a draft Directive setting the fourth list of the indicative values is being prepared. For chemicals such as asbestos, benzene, hardwood dust, lead and its inorganic compounds, vinyl chloride monomer, the binding values have been set at the Community level.

\section{Basis for deriving the normative values in Poland}

The results of epidemiological studies performed to determine the relationship between the intensity and duration of occupational exposure and its health effects, the results of observations of volunteers and people exposed to specific agents harmful to health in industrial conditions, the results of studies on experimental animals serve as the basis for setting the normative values in Poland. All approaches used for the derivation of the admissible exposure limits are based on the assessment of the risk for changes in the health status of people in terms of harmful effect or changes that forecast the effect with varying degree of probability.

The NOAEL/NOAEC (non-observed adverse effect level/concentration), or the LOAEL (lowest observed adverse effect level), preferably adopted on the basis of chronic toxicity studies, are typically used as the starting point. Correction factors of uncertainty are applied to calculate the MAC value from the NOAEL or LOAEL. Typically, the recommended exposure limit is derived from only one measurable toxic effect, known as the critical effect. For carcinogens, the recommended exposure limits are based on the concept of socially acceptable risk that ranges from $10^{-3}$ to $10^{-4}$, depending on whether the risk is expressed in terms of the incidence of changes in health status during 1 year or during the whole lifetime. For irritant substances, the MAC value may be derived from data on the Respiratory Rate Decrease $\left(\mathrm{RD}_{50}\right.$ - the dose of the irritant absorbed with the inhaled air causing a reduction in respiratory rate to $50 \%$ of the baseline value). 


\section{Analysis of occupational exposure limit monographs prepared in 2002-2013}

Out of 122 IOELV values for chemicals valid in the EU, the MAC values valid currently in Poland are at the same level as in the Community for 57 of them, and for 65 of them the corresponding Polish values are at a lower level. The benefit of lower MAC values for some chemical substances in Poland is in part a legacy of the former USSR [18].

Analysis of 204 monographs of Polish occupational exposure limits prepared in 2002 to 2013 shows that for the 169 substances, the proposed value of the maximum admissible concentration is based on the LOAEL or NOAEL published in the literature (Table 1 and 2). For 80 substances (approx. 39\%), the proposed MAC value was based on irritation to eyes, skin or respiratory system. For other chemicals, the starting point was a systemic effect on the liver (31 substances), kidneys (19), central nervous system (23), the lungs and the respiratory tract (20), blood (17) and other systems and organs (36 substances), which included the cardiovascular system, metal fume fever, harmful effects on the fetus, reproductive system, thyroid, immune system, spleen, asthma, sensitization, peripheral nervous system, bone fluorosis, cholinergic function. In some cases, more than one effect was taken into account to determine the limit value for a substance.

The most difficult thing to assess was "the amount of available knowledge" and selection of major papers used to decide which effect was critical. The studies comprise 11127 scientific publications so, on average, there were approximately 56 publications per 1 monograph. The average number of used products increased over time, due to the emerging possibilities of rapid access to databases, monographs, reports, etc. Most literature (331 items) was collected for zinc and its inorganic compounds in 2012, and formaldehyde (298 items) in 2007. For 7 substances, the proposed MAC-TWA and MAC-STEL values were based on the RD50. For 63 substances admissible short-term values were determined.

Table 1. Substances, for which the MAC value has been set based on the LOAEL/NOAEL - depending on the route of administration Tabela 1. Substancje z wartością NDS ustaloną w oparciu o LOAEL/NOAEL - w zależności od drogi podania

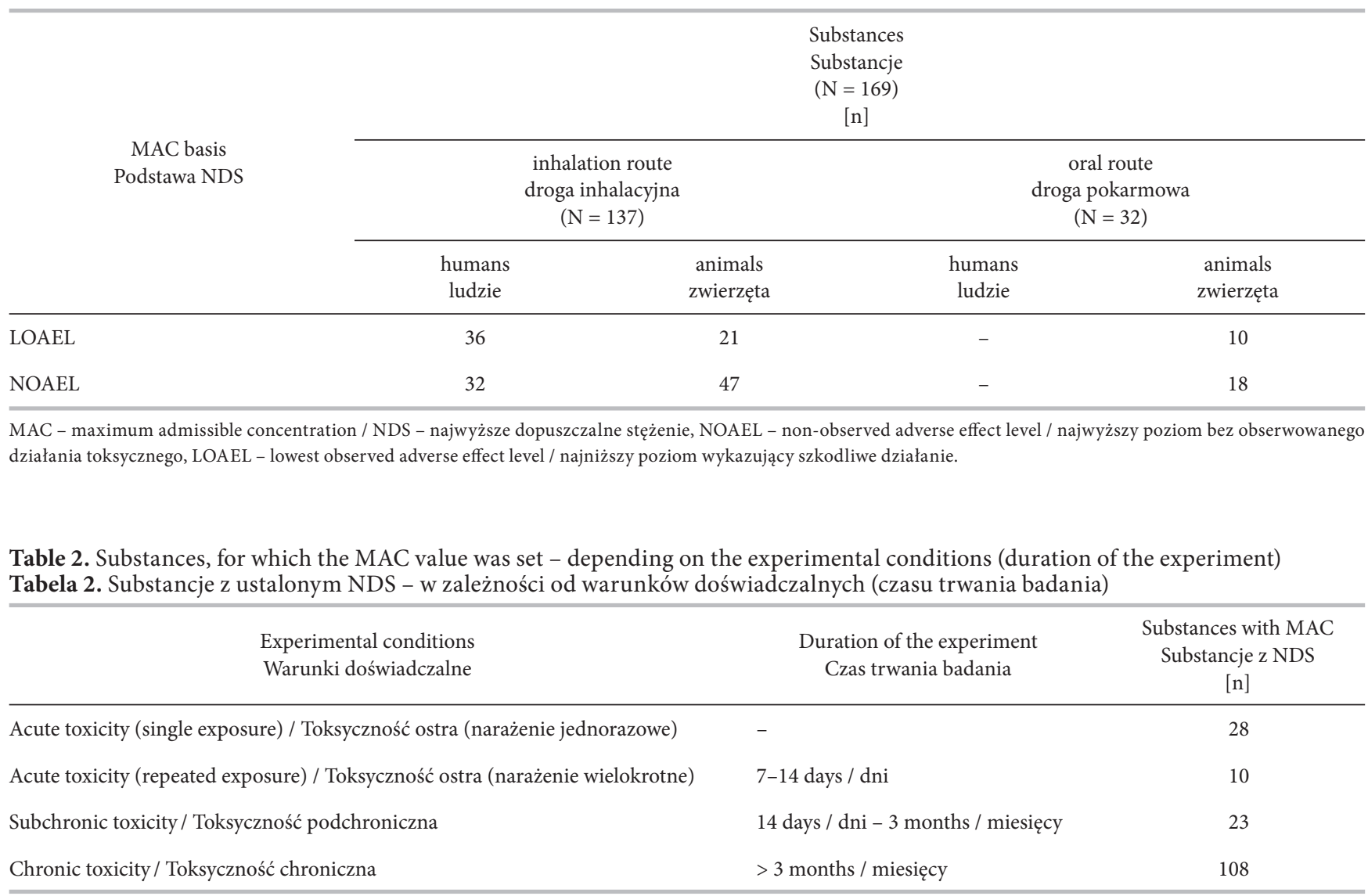

Abbreviations as in Table 1 / Skróty jak w tabeli 1. 
For the 6 substances classified as carcinogenic, the normative value was determined from the estimated cancer risk (Table 3), assuming the acceptable risk level of $10^{-3}-10^{-4}$. To develop those monographs, 780 publications were used, 98 per monograph on average.

According to the rules for setting the hygiene standards in the EU, the OEL values for the above carcinogens, exposure to which occurs in the industry, have not been established, and therefore there is a need to monitor their concentrations in the air of the working environment.

As it is not possible to determine the dose-effect in humans and/or animals, the MAC for 12 substances has been proposed by analogy to other substances with a similar activity or by analogy to the MAC values specified by other organizations dealing with the setting of hygiene standards, such as e.g., the ACGIH or the German Commission for the Investigation of Health Hazards of Chemical Compounds in the Work Area. Those chemicals include nitrogen oxide, carbon monoxide, picric acid, propene, trimellitic anhydride, thionyl chloride, trichloroacetic acid, acetic anhydride, N-methylaniline, phosphoryl trichloride, dimethyl phthalate, and cyclopentane. In developing these records 468 publications were used, 39 per monograph on average.

To calculate the MAC value from the NOAEL or LOAEL, correction factors of uncertainty were applied, taking into account interspecies differences and route of administration (route of administration other than inhalation) - to 10 ; differences in individual sensitivity - to 2; transition from short-term to longterm studies - up to 3; the use of a LOAEL instead of a NOAEL - to 3; as well as adjustments for incompleteness or poor quality of available data on toxicity - to 5 .

The total uncertainty factor (UF) was a product of the coefficients involved. The combined UF showed variability range 1-40 (mean 8.1). For the MAC values derived from human NOAELs and LOAELs, the averaged UFs are 2.3 and 4.4, respectively. For 10 healthbased OELs set between 2003 and 2013, the UF of 1 was used to derive OELs from human. For MAC values derived from animals' NOAELs and LOAELs, the averaged UFs are 10.3 and 14.8, respectively. No correlation between the number of references and UF is found. However, the use of references in the summary documents seems to increase over time. No correlation between the number of references, kind of critical effect, time of exposure and combined UF is found.

Schenk and Johanson [19] in 2010 performed a study on how the Scientific Committee on Occupational Exposure Limits (SCOEL) of the European Commission uses uncertainty factors when proposing healthbased IOELVs. In total, 75 IOELVs in 62 summary documents published from 1991 to 2003 were analyzed. Significant differences in the magnitude of the explicit uncertainty factors (EUFs) used to derive healthbased IOELVs were found. Explicit uncertainty factors showed variability range from 1 to 50 . The magnitude of the EUFs was the same, regardless of whether lack

Table 3. Carcinogenic substances, for which values of hygienic standards were set determined from the estimated risk of cancer Tabela 3. Substancje rakotwórcze, dla których wartości normatywów higienicznych wyznaczono na podstawie oszacowanego ryzyka wystąpienia raka

\begin{tabular}{ccc}
\hline Substance & MAC & Cancer type \\
Substancja & $\mathrm{NDS}$ & Rodzaj nowotworu \\
{$[\mathrm{CAS}]$} & {$\left[\mathrm{mg} / \mathrm{m}^{3}\right]$} &
\end{tabular}

4,4'-methylenedianiline / 4,4'-metylenodianilina [101-77-9]

Buta-1,3-diene / Buta-1,3-dien [106-99-0]

Bromoethene (vinyl bromide) / Bromoeten (bromek winylu) [593-60-2]

1,2-dibromoethane / 1,2-dibromoetan [106-93-4]

Cadmium and its inorganic compounds (as Cd) / Kadm i jego związki nieorganiczne (jako Cd) [7440-43-9]
0.08

4.40

0.40

0.01

0.01

(dusts and fumes / pyły i dymy)

0.002

(respirable fraction / frakcja respirabilna) thyroid cancer / rak tarczycy

lymphohematopoietic cancers / nowotwory układu limfohematopoetycznego

hemangiosarcoma / naczyniomięsak krwionośny

nasal tumours / nowotwory nosa pulmonary cancer / rak płuca 
of data was stated or not (geometric means: 4.9 vs. 4.5). No correlation between the number of references and the EUF is found. However, the use of references in the summary documents seems to increase over time.

For 24 health-based OELs set in the UK between 1990 and 1993, the UF of 1 was used to derive OELs from human NOAELs from studies judged of high quality. When the OEL was derived from a human LOAEL and the critical effect was of little health significance, an average UF of 2 was applied. For OELs derived from animal NOAELs and LOAELs, the UFs used ranged; $2.5-11$ and 4-12, respectively. If the OELs were based on reproductive or teratogenic effects the average UFs were higher, and the range of UFs was wider. Uncertainty factors used in Poland are higher than in the UK (Table 4). This probably results from the application of the correction for incompleteness or poor quality of the accessible toxicity data. When calculating MAC from NOAEL/animals, in some instances a factor of $1 / 2$ was applied to account for interspecies differences in rat and human breathing, thus it was possible to obtain a total uncertainty factor equal to 1 .

\section{CONCLUSIONS}

Since 2002, activities in the field of hygiene standards in the countries of the former Eastern Bloc have been correlated with EU policy. The functioning of the system of the MAC setting in Poland for many years before the entry into the Community has allowed a relatively quick adjustment of Polish regulations on chemicals to the relevant European law. During 2002-2013 in Poland, 204 monographs on occupational exposure limits were prepared, out of which the bulk (84) was compiled in 2002-2004, when intensive efforts were undertaken to harmonize Polish legislation in the field of the policy on chemicals with that of the European Union. Currently, the Polish list includes 543 substances.

In the former Eastern Bloc countries, intensification of work after joining the EU has caused that the lists in those countries contain from 285 substances in Slovakia to 780 in Lithuania.

Currently, all substances included in the EU lists (up to and including the third list) have been governed by the Polish, Lithuanian, Czech, Latvian and Hungarian law. In other countries of the Eastern Bloc, Estonia and Slovakia have implemented the provisions of the Directive 2006/15/EC establishing the second list of occupational exposure limits.

It should be emphasized that individual national lists contain much more chemicals than the EU list containing currently 122 substances. The legislative process in the $\mathrm{EU}$ is slow, and that is why the national law is important and necessary due to local needs in selected areas and the necessity to arrive at solutions to problems on an individual basis.

In Poland, the MAC values have been set for substances, for which standards of hygiene have been long-awaited and deemed to be necessary by workers and employers for the assessment of e.g., isocyanates used in the production of polyurethane elastomers methylenediphenyldiisocyanate $(\mathrm{MDI})=0.03 \mathrm{mg} / \mathrm{m}^{3}$,

Table 4. Comparison of uncertainty factors in the United Kingdom and Poland Tabela 4. Porównanie współczynników niepewności w Wielkiej Brytanii i Polsce

\begin{tabular}{|c|c|c|}
\hline \multirow[b]{2}{*}{$\begin{array}{l}\text { MAC basis for calculation } \\
\text { Podstawa wyliczenia NDS }\end{array}$} & \multicolumn{2}{|c|}{$\begin{array}{c}\text { Uncertainty factor } \\
\text { Współczynnik niepewności }\end{array}$} \\
\hline & $\begin{array}{l}\text { United Kingdom } \\
\text { (value or range) } \\
\text { Wielka Brytania } \\
\text { (wartość lub zakres) }\end{array}$ & $\begin{array}{c}\text { Poland } \\
{[\mathrm{M} \text { (range) }]} \\
\text { Polska } \\
{[\mathrm{M} \text { (zakres) }]}\end{array}$ \\
\hline LOAEL & 2 & $4.4(2-8)$ \\
\hline \multicolumn{3}{|l|}{ Animals / Zwierzęta } \\
\hline NOAEL & $2.5-11$ & $10.3(1-40)$ \\
\hline
\end{tabular}

$\mathrm{M}$ - mean / średnia.

Other abbreviations as in Table 1 / Inne skróty jak w tabeli 1. 
hexamethylene diisocyanate $(\mathrm{HDI})=0.04 \mathrm{mg} / \mathrm{m}^{3}$, tolylidene diisocyanate $(\mathrm{TDI})=0.007 \mathrm{mg} / \mathrm{m}^{3}$. More recently, work has been undertaken to establish normative values for the selected cytostatics (cyclophosphamide, methotrexate). In Slovakia, hygiene standards have been established for rubber components such as dithiocarbamates $\left(2 \mathrm{mg} / \mathrm{m}^{3}\right)$, thiazole $\left(4 \mathrm{mg} / \mathrm{m}^{3}\right)$, while Lithuania has set the normative values for boron carbide used in ramjet fuel $\left(6 \mathrm{mg} / \mathrm{m}^{3}\right)$ or bromobenzenes used in organic synthesis $\left(3 \mathrm{mg} / \mathrm{m}^{3}\right)$. In turn, Latvia has limits for aminoacid such as valine $\left(5 \mathrm{mg} / \mathrm{m}^{3}\right)$ or the commonly used ammonium hydrogen phosphate mineral fertilizer $\left(6 \mathrm{mg} / \mathrm{m}^{3}\right)$. In Estonia, admissible limit values have been established for [(p-tolyloxy)methyl] oxirane used in cosmetics.

Lack of hygiene standards for modern anaesthetic gases strongly limited the possibility of assessing exposure of medical personnel to these substances. In Poland in 2007, the MAC-TWA values were set for anaesthetics, such as sevoflurane $\left(55 \mathrm{mg} / \mathrm{m}^{3}\right)$, isoflurane $\left(23 \mathrm{mg} / \mathrm{m}^{3}\right)$ or desflurane $\left(125 \mathrm{mg} / \mathrm{m}^{3}\right)$. Other countries also have paid attention to this problem and established admissible levels of exposure to those drugs. Different approaches to setting hygiene standards caused that in Slovakia the MAC-value for desflurane is $70 \mathrm{mg} / \mathrm{m}^{3}$, while in the Czech Republic the corresponding value is $30 \mathrm{mg} / \mathrm{m}^{3}$.

In the light of the above data, it is necessary to correlate the activities in the field of determining the regional OEL values in the countries of the former Eastern Bloc and the EU and to exchange the information resulting from the processing of huge amounts of literature data. Setting of hygiene standards should be noncompetitive because, regardless of the state, it serves one purpose, which consists in the safe operation and improvement of working conditions by minimizing the risks arising from exposure to chemicals.

\section{REFERENCES}

1. Czerczak S, Indulski J, Kowalski Z, Szymczak W. [The methodology for determining occupational and environmental hygiene standards]. Med Pr. 1994;3 Suppl 2:5-88. Polish.

2. [Regulation of the Minister of Labour and Social Policy from 6th June 2014 on the maximum permissible concentrations and intensities of harmful factors in the work environment. J Laws 2014, item 817 as amended (Jun 23, 2014)]. Polish.

3. [Slovak Government Regulation from 23rd November 2011 amending Regulation Government of the Slo- vak Republic of 2006 No. 355 Coll. The protection of workers from risks related to exposure to chemical agents at work in the zen of the Government of the Slovak Republic of 2007 No. 300 Coll. Collect Laws 2011, No. 471]. Available from: www.zbierka.sk/sk/predpisy/471-2011-zz.p-34436.pdf. Slovak.

4. [Lithuanian Hygiene Standard of 2011 HN 23. Occupational exposure limit values measuring and assessing the impact of general requirements for approval]. Available from: http://www.e-tar.lt/portal/legalact.html?documen tid=tar.8012ed3ea143. Lithuanian.

5. [The Government of the Republic Regulation from 18th September 2001. Occupational exposure limits for No. 293, change adopted No. 223 (October 11, 2007)]. Available from: http://www.riigiteataja.ee/akt/12872786. Estonian.

6. [Occupational health and safety requirements for exposure to chemicals at work Cabinet of Ministers No. 325 issued pursuant to Section 25 of the Labour Protection Clause 11 and 16 of the Law on Chemicals (MK February 1, 2011 regulations No. 92 version) in Riga, May 15, 2007]. Available from: http://likumi.lv/doc. php?id=157382. Latvian.

7. [Czech Government Regulation Act from 12th of December 2007 laying down the conditions for the protection of health at work No. 361sb as amended: of 2010 No. 68 Coll., of 2012 No. 93 Coll., of 2013 No. 9 sb. J Laws No. 111/2007, January 1, 2008, p. 5086]. Available from: http://www.tzb-info.cz/pravni-predpisy/narizenivlady-c-361-2007-sb-kterym-se-stanovi-podminkyochrany-zdravi-pri-praci. Czech.

8. [Health Minister Regulation on chemical safety on the job EUM TLV from 30th September 2000 No. 25]. Available from: http://net.jogtar.hu/jr/gen/hjegy_doc.cgi? docid=A0000025.EUM. Hungarian.

9. [Law from 26th June 1974 Labour code. J Laws 1974 No. 24, item 141]. Available from: http://isap.sejm.gov.pl/ DetailsServlet?id=WDU19740240141. Polish.

10. [Regulation of the Prime Minister from 28th May 1996 on appointment of Interdepartamental Commission for Maximum Admissible Concentrations and Intensities for Agents Harmful to Health in the Working Environment. J Laws 1996 No. 61, item 284]. Polish.

11. [Directive 2009/161/EU from 17th December 2009 establishing a third list of indicative occupational exposure limit values in implementation of Council Directive 1998/24/EC and amending Commission Directive 2000/39/EC. Off J Eur Union L 338, p. 87]. Polish.

12. [Directive 2006/15/EC from 7th February 2006 establishing a second list of indicative occupational exposure 
limit values in implementation of Council Directive 1998/24/EC and amending Directives 1991/322/EEC and 2000/39/EC. Off J Eur Union L 38 (Feb 9, 2006), p. 36]. Polish.

13. Ungváry G, Folly G. [Newly developed mathematical method for the animal experimental hygienic norm setting for organic solvents. Toluene]. Munkavédelem, Munka- és Üzemegészségügy 1984;30(4-6):91-7. Hungarian.

14. Ungvary G, Tatrai E. On the embryotoxic effects of benzene and its alkyl derivatives in mice, rats and rabbits. Arch Toxicol. 1985;8(Suppl):425-30.

15. [Directive 1998/24/EC from 7th April 1998 on the protection of the health and safety of workers from the risks related to chemical agents at work (fourteenth individual Directive within the meaning of Article 16(1) of Directive 1989/391/EEC. Off J Eur Union L 131 (May 5, 1998)]. Polish.

16. [Directive 1991/322/EEC from 29th May 1991 on establishing indicative limit values by implementing Council
Directive 1980/1107/EEC on the protection of workers from the risks related to exposure to chemical, physical and biological agents at work. Off J Eur Union L 177 (Jul 5, 1991), p. 412]. Polish.

17. [Directive 2000/39/EC from 8th June 2000 establishing a first list of indicative occupational exposure limit values in implementation of Council Directive 1998/24/EC on the protection of the health and safety of workers from the risks related to chemical agents at work. Off J Eur Union L 142 (Jun 16, 2000), p. 432]. Polish.

18. Skowroń J. [Safe and healthy working conditions in Poland - The role and mission of the Interdepartmental Commission for Maximum Admissible Concentrations and intensities for agents harmful to health in the working environment]. Bull Bureau Chem. 2012;4:21. Polish.

19. Schenk L, Johanson G. Use of uncertainty factors by the SCOEL in their derivation of health-based occupational exposure limits. Crit Rev Toxicol. 2010;40(9): 791-8, http://dx.doi.org/10.3109/10408444.2010.507628.

This work is available in Open Acces model and licensed under a Creative Commons Attribution-NonCommercial 3.0 Poland License / Ten utwór jest dostępny w modelu open access na licencji Creative Commons Uznanie autorstwa - Użycie niekomercyjne 3.0 Polska - http://creativecommons.org/ licenses/by-nc/3.0/pl/deed.en. 